\title{
Using LANDSAT Imagery for Analysis of Built Land Index in Semarang City
}

\author{
Tjaturahono Budi Sanjoto ${ }^{1}$, Erni Suharini ${ }^{2}$, Leo Wibowo Seta Nugraha ${ }^{3}$ \\ \{tjatur@mail.unnes.ac.id\}
}

Universitas Negeri Semarang, Indonesia ${ }^{1,2,3}$

\begin{abstract}
Semarang City as one the biggest city in Indonesia is still growing as a result of the population continues to grow. This condition results in an increase in the area of land being built. The increase in uncontrolled built-up land can result in changes in surface temperature conditions. The main objective of the study was to determine the development of the index of built-up land in Semarang City from 1997-2017. The object of this study includes land cover, index of built up land in the city of Semarang. This study uses several methods of data collection, namely interview methods, image interpretation, surveys, and secondary data documentation. The tools and materials used were Landsat 5 TM imagery recording on 15 August 1997, Landsat 5 TM imagery recording on 27 August 2007, and Landsat 8 OLI / TIRS Imagery recording on 22 August 2017. For the analysis of built-up land through interpretation of satellite imagery assisted by using the NDBI algorithm NDBI=(SWIR-NIR)/(SWIR+NIR) The results of the study showed that within a period of 20 years the index of land constructed in very high categories experienced a significant change. In 1997 the area of the Very Built Land Index reached $17.74 \%$, then in 2002 it reached $18.42 \%$ and in 2017 it reached an area of $21.88 \%$. With the broader NDBI category very high, this can cause a rise in surface temperature which in turn will make Semarang City uncomfortable as a residential city.
\end{abstract}

Keywords: Built Land, NDBI, Landsat Imagery.

\section{Introduction}

Semarang City is the capital city of Central Java Province which is developing towards a metropolitan city. Various facilities available in Semarang City attract people to come and live in this city. Therefore, the population in the city of Semarang continues to increase.

The results of the 2010 Population Census of the Statistics Central Bureau [1] show Semarang City to be the city with the highest number of populations of Lima in Indonesia totaling 1,527,433 people. Based on the records of the Semarang City Population and Civil Registration Service, the population per June 2019 reached 1,815,729 people (dispendukcapil.semarangkota.go.id). 
This increase in population causes changes in land use. There is a lot of land conversion into industrial estates, residential areas that are the cause of reduced green open space. Traffic congestion that often occurs in several places is a problem that began to haunt Semarang City. The effect is the comfort level of Semarang City as a residential location to be reduced. The density of the building causes during the day the air temperature in the city of Semarang to become hot. However, the average temperature of Semarang City reaches 28 degrees.

Observations regarding changes in land use, especially built land, can be made using the existence of remote sensing technology. The use of remote sensing technology using satellite imagery such as Landsat Imagery that has a medium level of spatial resolution that also has many channels or bands allows Landsat Imagery to perform image composites and extract various indices to detect information on built up land [2]. One method that is often used in detecting built-up land using Landsat Imagery is NDBI (Normalized Difference Built-up Index), NDBI has been used by [3] to map urban land in Nanjing China. The mapping results show that the accuracy reaches $92.6 \%$.

Fariz [2] also conducted research using NDBI to detect settlement density estimates and combine with the OBIA classification in Pontianak City Indonesia. The mapping results show that the built land index has a strong determination value (R2) that is equal to 0.628 and has a strong enough correlation of 0.792 for settlement density.

Based on the description above, this study aims to examine the development of the constructed land index of Semarang City in 1997-2017 using LANDSAT imagery.

\section{Research Method}

This research was carried out in the city of Semarang. The image used is Landsat 5 TM recording on 15 August 1997, Landsat 5 TM image recording on 27 August 2007, Landsat 8 OLI / TIRS image recording on 22 August 2017. Techniques of data analysis using the Normalized Difference Builtup Index, using algorithms [3]:

\section{NDBI $=($ SWIR - NIR $) / S W I R+N I R$}

$$
\begin{array}{ll}
\text { SWIR } & =\text { Middle Infrared Channel } \\
\text { NIR } & =\text { Near Infrared Channel }
\end{array}
$$

\section{a. Pre-Processing of NDBI Data}

The pre-image processing activity used is radiometric calibration to change the value of the digital number of Landsat $5 \mathrm{TM}$ imagery to the value of ToA reflectance [2] the formula used as follows.

$$
\rho_{P}=\frac{\Pi \cdot L_{\lambda} \cdot d^{2}}{\operatorname{ESUN}_{\lambda} \cdot \cos \theta_{s}}
$$




$$
\begin{array}{ll}
\mathrm{L}_{\Lambda} & =\text { Spectral radiance at sesnsor aperture } \\
d^{2} & =\text { earth-sun distance in astronomical units } \\
\mathrm{ESUN}_{\Lambda} & =\text { mean solar exoatmosphere irradiance } \\
\cos \theta_{\mathrm{s}} & =\text { Solar zenith angle in degree }
\end{array}
$$

Then changing the value of the digital number to reflectance of Landsat 8 OLI / TIRS Image [8] using the following formula

$$
\rho_{\lambda}=\frac{\rho_{i}^{*}}{\cos \left(\theta_{S Z}\right)}=\frac{\rho_{i}^{*}}{\sin \left(\theta_{S E}\right)}
$$

$$
\begin{array}{ll}
\rho_{\Lambda} & =\text { ToA planetary reflectance } \\
\theta_{\mathrm{SE}} & =\text { Local sun elevation angle } \\
\theta_{\mathrm{SZ}} & =\text { Local solar zenith angle }
\end{array}
$$

\section{b. Processing NDBI Data}

After LANDSAT 5 and LANDSAT 8 imagery are calibrated so that the digital number value is recycled, NDBI processing can be continued using the NDBI algorithm [6]

$$
\mathrm{NDBI}=(\mathrm{SWIR}-\mathrm{NIR}) / \mathrm{SWIR}+\mathrm{NIR}
$$

The index value is then classified into 5 classes of built land indexes

Table 1. Classification of the Built Land Index

\begin{tabular}{ll}
\hline Density Class & Index value \\
\hline Very low & $<-0.2$ \\
\hline Low & $(-0.2)-(-0.15)$ \\
\hline Middle & $(-0.15)-(-0.1)$ \\
\hline High & $(-0.1)-0$ \\
\hline Very high & $>0$ \\
\hline
\end{tabular}

\section{Research Results and Discussions}

Based on the results of the research, the development of the index of built-up land in Semarang City has changed since 1997. Changes in the built land index that have been observed, the 
development of built land has expanded to the suburbs, this can also be seen in surface temperatures which also increase especially in suburban Semarang. The results of the study will be divided into several points as follows

\section{a. Built Land Index in Semarang City (1997 - 2017)}

The constructed land index results use the Normalized Difference Built-up Index (NDBI) formula to get statistical results in the form of:

Table 2. NDBI Semarang City

\begin{tabular}{lll}
\hline Year & Maximum & Minimum \\
\hline $\mathbf{1 9 9 7}$ & 0,58 & $-1,0$ \\
\hline $\mathbf{2 0 0 7}$ & 0,49 & $-1,0$ \\
\hline $\mathbf{2 0 1 7}$ & 0,46 & $-1,0$
\end{tabular}

Furthermore, the results of processing using the NDBI formula are classified according to the NDBI class that has been determined, as follows:

Table 3. Class Area NDBI

\begin{tabular}{l|lllllll} 
No & Class NDBI & Area 1997 & $\% 1997$ & Are 2007 & $\% 2007$ & Area 2017 & $\% 2017$ \\
\hline 1 & Very low & 12086,30 & 31,38 & 11660,72 & 30,28 & 14843,89 & 38,54 \\
2 & Low & 3681,02 & 9,56 & 3955,92 & 10,27 & 3604,90 & 9,36 \\
3 & Middle & 4641,00 & 1205 & 4796,67 & 12,45 & 3757,11 & 9,76 \\
4 & High & 11273,26 & 29,27 & 11006,62 & 28,58 & 7878,62 & 20,46 \\
5 & Very high & 6831,69 & 17,74 & 7092,71 & 18,42 & 8427,07 & 21,88
\end{tabular}

Source: Research Result

In the low class, it has an area of 3681 ha in 1997, or around $9.56 \%$ of the total area of Semarang City. The distribution of low classes in 1997 was spread across sub-districts or areas that are on the outskirts of Semarang, such as Gunungpati, Mijen, Ngaliyan and Pedurungan. 


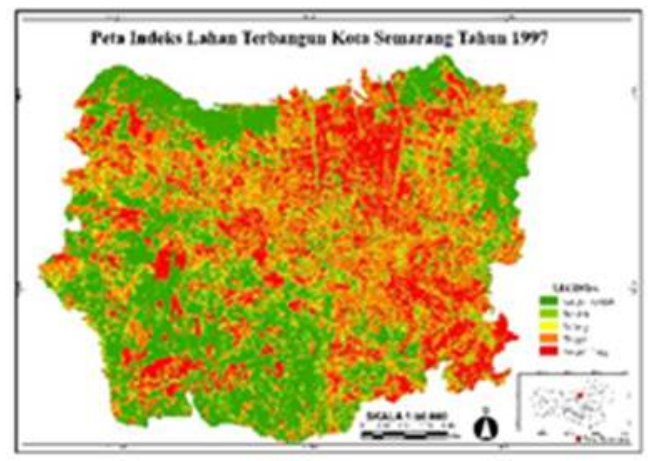

Figure 1. Map of the Built Land Index in 1997

Medium class land in 1997 had an area of 4641 ha, or $12.05 \%$ of the total area of Semarang City. The distribution of classes is in Banyumanik, Pedurungan, Gunungpati, Tembalang Districts. In 1997 the high class had an area of 11273 ha or $29.57 \%$ of the land area of Semarang City. The distribution of high class is in West Semarang District, Gajahmungkur, Candisari, Gayamsari, Mijen, Ngaliyan, Genuk

In 1997 the class was very high with an area of 6831 ha, or about $17.74 \%$ of the area of Semarang City. Distribution in the city center and suburbs that have vacant land such as Tembalang, Ngaliyan, and Mijen Subdistricts. At the center of Semarang City, such as East Semarang District, South Semarang, Candisari, and Gayamsari.

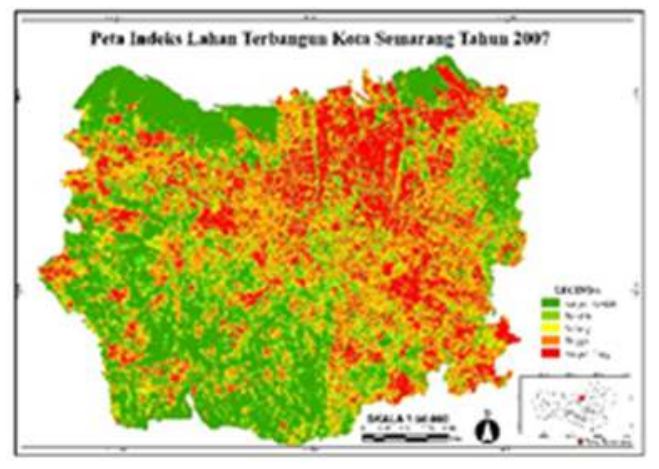

Figure 2. Map of the Built Land Index in 2007

In 2007 the class area was very low with an area of 11660 ha or around $30.28 \%$ of the total area of Semarang City. This area decreased compared to 1997. The distribution of very low classes still tended to be the same as in 1997 with almost no change.

This area has increased in 2007 to 3955 ha or around 10.27\%, in 2017 the low area has an area of 3604 ha or about $9.36 \%$ of the total area of Semarang City. 
In 2007 the value of the medium class area was 4796 ha or around $12.45 \%$ of the total area of Semarang City. Distribution of medium class land in 2007, namely in Gunungpati, Pedurungan, Ngaliyan, Banyumanik Districts.

In 2007 the area of high class was 11006 ha or $28.58 \%$ of the total area of Semarang. The distribution of the high class in 2007 was spread evenly, but in the central part of Semarang City the most dominated such as East Semarang District, West Semarang, Gajahmungkur, Mijen, and Tembalang.

In 2007 the area of the class was very high at 7092 ha or $18.42 \%$ of the total area of Semarang, the distribution of very high classes in 2007 was spread evenly, but in the central part of Semarang the most dominant areas were East Semarang, South Semarang, Gajahmungkur, Mijen, Ngaliyan and Tembalang.

In 2017 very low-class area has an area of up to 14843 ha, there was a broad increase compared to 1997 and 2007, around $38.54 \%$ of the total area of Semarang City was very low class. Even very low-class distribution can be found, in Mijen, Gunungpati, Tugu and Genuk Subdistricts. In 2017 the low area has an area of 3604 ha or about $9.36 \%$ of the total area of Semarang.

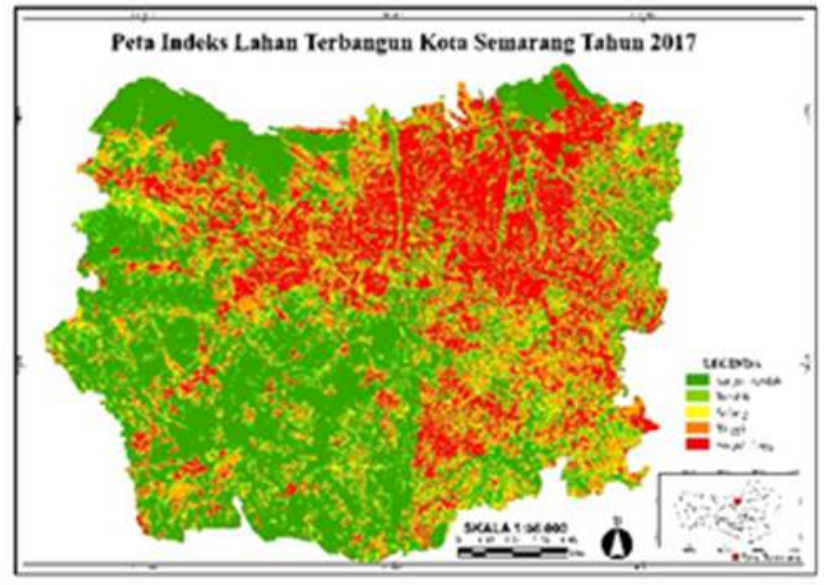

Figure 3. Map of the Built Land Index in 2017

In 2017 the average class area is 3757 ha or an area of $9.76 \%$ of the land area of Semarang City. Medium class distribution in 2017 is not much different in 2007, namely in Gunungpati, Pedurungan, Ngaliyan, Banyumanik Districts.

In 2017 the middle class has an area of 7878 ha or $20.46 \%$. The significant decrease in area was caused by a decrease in land cover in the form of low-density vegetation. So that causes the highclass area to decrease in area.

In 2017 the class is having an area of 8427 ha, or about $21.88 \%$ of the total area of Semarang, the distribution is more widespread and in 2017 land cover dominates the high land class, which is already built up land. 


\section{b. Relations NDBI with Building Density}

The NDBI value obtained from the processing using the NDBI algorithm with the data used in the latest image recording in 2017 is checked by the condition of building density in the field. There were 30 samples used to test NDBI values in the field. This test was conducted to examine the relationship between NDBI values and building density values.

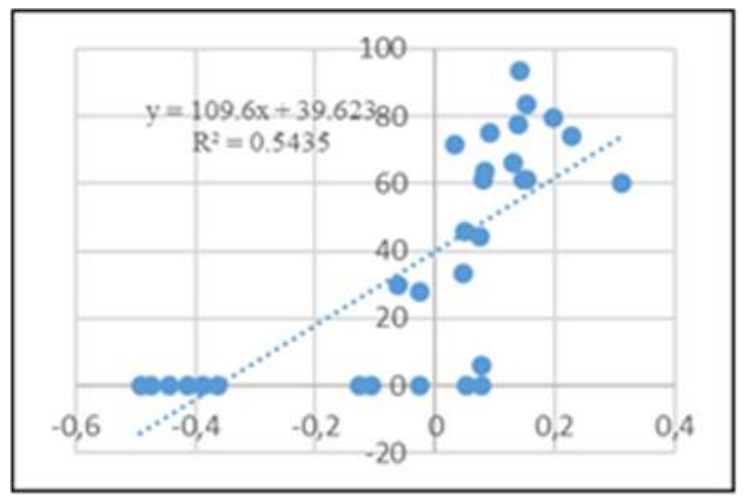

Figure 4. Relation of NDBI with Building Density

Determinant factors $\left(\mathrm{R}^{2}\right)$ the relationship between NDBI and building density gets a result of 0.5435 and a correlation number of 0.7372 . This also indicates that there is a relationship between the NDBI value resulting from processing in the Satellite Image and the value of building density in the field.

\section{Conclusions}

The use of Landsat Imagery can be used to produce index data on built-up land in the city of Semarang using the NDBI algorithm by utilizing near infrared channels and short infrared so that the index of constructed land data can be generated. The index of built up land in the city of Semarang, which has a high-density value, was in areas in the center of Semarang City in 1997, but along with the increase in land built in 2017, the suburbs of Semarang.

Use of Landsat imagery can be used to produce data in the form of surface temperature. Utilizing thermal channels on channel 6 in Landsat 5 and channel 10 imagery in Landsat Image 8. The processing results show that the class of built up land and empty land has the highest surface temperature compared to the others, while the water body is the coldest land cover class. 


\section{References}

[1] B. P. S. 2010., Semarang Dalam Angka Tahun 2010. Semarang: Badan Pusat Statistik Kota Semarang.

[2] R. T. Fariz, "OBIA Classification Andbuilt-Up Land Indices Ndbi For Estimastion Of Settlement Density In Pontianak City," J. Geogr., vol. 14, no. 2, pp. 2549-3094, 2017.

[3] Y. Zha, J. Gao, and S. Ni, "Use of normalized difference built-up index in automatically mapping urban areas from TM imagery,” Int. J. Remote Sens., vol. 24, no. 3, pp. 583-594, 2003. 